The Making of Experimental Economics 

Andrej Svorenčík • Harro Maas

Editors

\section{The Making of Experimental Economics}

Witness Seminar on the Emergence of a Field

粤 Springer 


\section{Editors}

Andrej Svorenčík

Department of Economics

University of Mannheim

Mannheim, Germany

\author{
Harro Maas \\ Centre Walras-Pareto d'études \\ interdisciplinaires de la pensée \\ économique et politique - IEPI \\ Université de Lausanne \\ Lausanne, Switzerland
}

ISBN 978-3-319-20951-7

ISBN 978-3-319-20952-4 (eBook)

DOI 10.1007/978-3-319-20952-4

Library of Congress Control Number: 2015947288

Springer Cham Heidelberg New York Dordrecht London

(C) Springer International Publishing Switzerland 2016

This work is subject to copyright. All rights are reserved by the Publisher, whether the whole or part of the material is concerned, specifically the rights of translation, reprinting, reuse of illustrations, recitation, broadcasting, reproduction on microfilms or in any other physical way, and transmission or information storage and retrieval, electronic adaptation, computer software, or by similar or dissimilar methodology now known or hereafter developed.

The use of general descriptive names, registered names, trademarks, service marks, etc. in this publication does not imply, even in the absence of a specific statement, that such names are exempt from the relevant protective laws and regulations and therefore free for general use.

The publisher, the authors and the editors are safe to assume that the advice and information in this book are believed to be true and accurate at the date of publication. Neither the publisher nor the authors or the editors give a warranty, express or implied, with respect to the material contained herein or for any errors or omissions that may have been made.

Printed on acid-free paper

Springer International Publishing AG Switzerland is part of Springer Science+Business Media (www.springer.com) 


\section{Contents}

\section{A Witness Seminar on the Emergence of Experimental}

Economics . . . . . . . . . . . . . . . . . . . . . . . . 1

Harro Maas and Andrej Svorenčík

Introduction . . . . . . . . . . . . . . . . . . . . . 1

The Method of the Witness Seminar................. 2

Background to the Witness Seminar on the Experiment

in Economics............................ 5

Preparation of the Seminar.................... 7

Whom to Invite and Why? . . . . . . . . . . . . . . . 7

What Topics to Cover and Why? ..................... 9

How to Prepare for and Organize the Seminar . . . . . . . . . . . . 10

The Seminar and Its Results . . . . . . . . . . . . . . . . . . 12

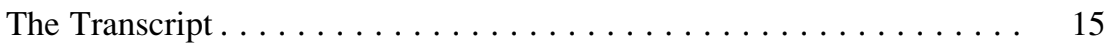

How to Read the Transcript of the Witness Seminar............ 16

References........................... 17

2 The Very Beginnings . . . . . . . . . . . . . . . . . . . . . 19

Choosing a Dissertation Topic ....................... 19

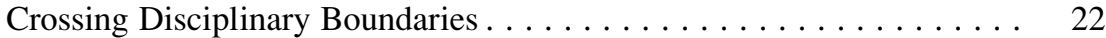

Early Meetings and Seminars .................... 27

Chance Encounters and Conversions . . . . . . . . . . . . 28

The JEL-Code and Closeted Experimentalists on the Job Market . . . . . 37

Institutional Settings . . . . . . . . . . . . . . . . . 41

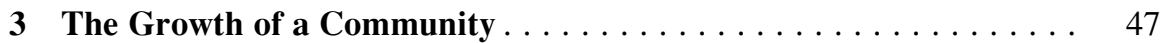

The German Experimental Community . . . . . . . . . . . . . . 47

Caltech, Public Choice, and the "Experimental Bug".......... . 50

The Tucson Meetings, the NSF, and Dan Newlon ............ 52

Bringing Experiments to a Larger Audience . ............ 55

Struggle for Acceptance or Standard Battles with Referees? . . . . . . . 58

Educating Editors $\ldots \ldots \ldots \ldots \ldots \ldots \ldots \ldots \ldots \ldots \ldots \ldots \ldots \ldots \ldots$ 


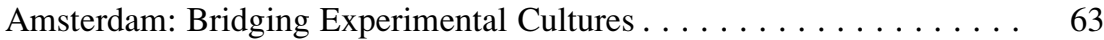

Internationalization and the Need for a Journal . . . . . . . . . . . 65

A Separate Journal: A Ghetto or a Premium Site to Publish? . . . . . . . 68

Lowering the Barrier to Entry: Editors and Handbooks . . . . . . . . 71

Dissents on Method.......................... 73

What Constitutes an Observation? Part I . . . . . . . . . . . . . 76

Payment and Deception: Spoiling the Subject Pool or Spilling

the Beans? . . . . . . . . . . . . . . . . . . . . . . . 77

What Constitutes an Observation? Part II . . . . . . . . . . . 80

Signs of Success: And the Resources It Takes . . . . . . . . . . . . 82

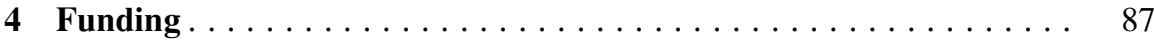

Payment: Tightening Up the Structure of the Model. . . . . . . . . . . 87

Paying the Subjects: Tax Money Spent on Frivolous Things . . . . . . . . 91

How to Fund an Economics Lab? . . . . . . . . . . . . . . . . . . . . . 97

Contract Money: The Best Kind of Money? . . . . . . . . . . . . . . . 100

Contract Research: Putting Careers at Risk . . . . . . . . . . . . . . . . . 104

Continuities Between the Lab and the World . . . . . . . . . . . . 106

The (Missing) Boilerplate in Contracts . . . . . . . . . . . . . . . . 108

The Experiment as Interface for Arguments . . . . . . . . . . . . . . . 110

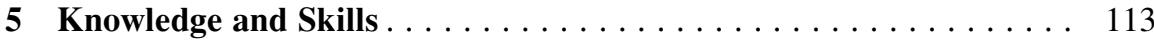

Learning from Failures............................ 114

Confused Subjects and the Logistics of an Experiment . . . . . . . . 118

Institutional Resistance to Experimental Results . . . . . . . . . . . 121

Isolating Confounding Factors and Learning from Them . . . . . . . 123

Costly Consequences of Actions: Who Will Pay for the Soufflés? . . . . 126

Anything You Change Can Make a Difference . . . . . . . . . . . . 129

How to Ask an Experimental Question? . . . . . . . . . . . . . . . . 134

Designing an Experiment Is a Joint Effort . . . . . . . . . . . . . . 136

Learning from Teaching. . . . . . . . . . . . . . . . . . 137

Thinking as an Experimenter........................ 144

Transferable Skills from Other Fields . . . . . . . . . . . . . . . . . 147

The Questions Depend on the Relevant Audience. . . . . . . . . . . . 150

Learning the Theory from Experiments . . . . . . . . . . . . 150

Discovering the Sub-game Perfect Equilibrium . . . . . . . . . . . . . 154

6 Laboratories . . . . . . . . . . . . . . . . . . . . . . . . . . . 157

The PLATO System . . . . . . . . . . . . . . . . . . . . . . . 157

Technology Changes the Message Space . . . . . . . . . . . . . . . 160

Austin Hoggatt's Visionary Laboratory . . . . . . . . . . . . . . . . . . 162

A Laboratory Is More Than Its Physical Infrastructure . . . . . . . . . . . 164

Space Fights: NASA Pays for Labspace . . . . . . . . . . . . . . . . 166

Portable Laboratories . . . . . . . . . . . . . . . . . . . . . . . . 168

The Management of Laboratories, Software, and Subject Pool . . . . . . 170

Lab Funding from an Administrator's Perspective . . . . . . . . . . . 173

Loosing Control . . . . . . . . . . . . . . . . . . . . . . . . . . . . . 174 
7 History and Future . . . . . . . . . . . . . . . . . . . . 177

How to Do Science and How to Name a Society? . . . . . . . . . . . . . . 177

SEEing Is Believing: Armchairs on Fire . . . . . . . . . . . . . . . . . . . . . . . . . . . . 178

An Anomaly Is Just Another Regularity . . . . . . . . . . . . . . . . . . . . . . . . . . . . . 180

Relics of the Past: And of the Future . . . . . . . . . . . . . . . . . 181

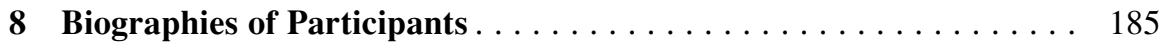

9 Episodes from the Early History of Experimentation

in Economics . . . . . . . . . . . . . . . . . . . . . . . . . . . . 195

Andreas Ortmann

Introduction . . . . . . . . . . . . . . . . . . . . . . . . . . . . 195

Episode One: The Wallis-Friedman (1942) Critique of the Thurstone

(1931) Experiment . . . . . . . . . . . . . . . . . . . . . 196

Episode Two: Morgenstern (1954) on Experiment and Large-Scale

Computation in Economics . . . . . . . . . . . . . . . . . . . . . . . . . 198

Episode Three: Thomas Juster (1970) on the Possibilities of

Experimentation and the Quality of Data Input in the

Social Sciences . . . . . . . . . . . . . . . . . . . . . . 203

Episode Four: Token Economy and Animal Models

for the Experimental Analysis of Economic Behavior

(Kagel \& Battalio, 1980) . . . . . . . . . . . . . . . . . . . . 206

Episode Five: Siegel's Work on Guessing Sequences . . . . . . . . . . . . . 209

Concluding Remarks . . . . . . . . . . . . . . . . . . . . . . 213

References ............................ 214

Erratum to: A Witness Seminar on the Emergence

of Experimental Economics . . . . . . . . . . . . . . . E1

Endnotes . . . . . . . . . . . . . . . . . . . . . . . . 219

References.............................. 235 